\title{
Clinical-statistical study of multiple synchronous and metacrone tumors
}

\section{Studiu clinico-statistic al tumorilor multiple sincrone şi metacrone}

\author{
Nicoleta Aurelia SANDA ${ }^{1}$, Radu Virgil COSTEA ${ }^{1,2}$, Cristian Constantin POPA ${ }^{1,2}$, \\ Daniela Aurora PEŞU ${ }^{1}, \mathrm{MR}^{\mathrm{RISTE}}{ }^{3}$, Ştefan Ilie NEAGU ${ }^{1,2,4}$ \\ ${ }^{1}$ Secţia de Chirurgie Generală II, Spitalul Universitar de Urgenţă, Bucureşti, România \\ ¿UMF "Carol Davila", Bucureşti, România \\ ${ }^{3}$ Secţia Chirurgie Plastică, Spitalul Judeţean, Constanţa, România \\ ${ }^{4}$ Academia Oamenilor de Ştiinţă din România
}

\section{ABSTRACT}

Multiple malignant tumors, synchronous, metachronous, represent a subject currently under development. Risk assessment, standardization of screening and and to map the sequences of the occurrence and localization represents current issues. For further study, we evaluated 30 patients who developed 3 or more malignancies. The study has a retrospective character, the information being obtained from the history and the medical documents of the patients admitted to the General Surgery II of the Bucharest Emergency Hospital during 2010-2019.
\end{abstract}

Keywords: multiple malignant tumors, synchronous, metachronous

\section{REZUMAT}

Tumorile maligne multiple, sincrone şi metacrone, reprezintă un subiect aflat încă în cercetare, evaluarea riscului, standardizarea screening-ului şi schematizarea secvențelor de apariție şi a localizării cancerului multiplu reprezentând teme actuale de studiu. Pentru aprofundarea acestora, au fost evaluați 30 de pacienți care au dezvoltat 3 sau mai multe tumori maligne. Studiul are un caracter retrospectiv, informațiile fiind obținute din istoricul şi documentele medicale ale pacienților internați în secția de Chirurgie Generală II a Spitalului de Urgență București în perioada 2010-2019.

Cuvinte cheie: tumori maligne multiple, sincron, metacron

\section{INTRODUCERE}

Tumorile maligne multiple, sincrone şi metacrone, reprezintă un subiect aflat încă în cercetare, evaluarea riscului, standardizarea screeningului şi schematizarea secvenţelor de apariţie şi a localizării cancerului multiplu reprezentând teme actuale de studiu. Termenii „sincron“ şi „metacron" nu sunt încă suficient de clar integraţi în diagnosticul cancerelor multiple, însă, la nivel internaţional, s-a conchis că tumorile maligne sincrone se vor numi astfel dacă au fost diagnosticate simultan sau la cel mult 6 luni distanţă în timp una de cealaltă, în timp ce cancerele metacrone se vor 
diferenţia de primele prin apariţia celui de-al doilea cancer la mai mult de 6 luni faţă de primul (15). Este necesară sublinierea faptului că două sau mai multe tumori pot fi sincrone sau metacrone indiferent de ţesutul la nivelul căruia au fost diagnosticate $(1,4-7)$. De exemplu, o femeie diagnosticată simultan cu un cancer de corp uterin şi unul de rect este încadrată între pacienţii cu tumori multiple sincrone, în timp ce un alt pacient cu un neoplasm de prostată şi unul de cec descoperite la mai mult de 6 luni este diagnosticat cu cancere metacrone. în mod similar, tumorile în organele pereche sau în organele cu diferite segmente (piele, tub digestiv) sunt considerate sincrone sau metacrone în funcţie de secvenţialitatea în timp $(8,9)$.

Condiţiile necesare pentru ca două sau mai multe tumori să fie considerate diferite (sincrone şi metacrone) şi nu etape secundare ale dezvoltării aceluiaşi cancer (recidive, metastaze) au fost elaborate încă din 1964 de către Moertel $(10,11)$ şi sunt următoarele:

1. Tumorile trebuie să fie distincte din punct de vedere histopatologic $(10,11)$ - buletinul histopatologic va exclude, aşadar, suspiciunea unei recidive sau a unei metastaze;

2. Când se află la nivelul aceluiaşi organ, ele trebuie să se situeze la o distanţă de minimum 4 $\mathrm{cm}$ una faţă de cealaltă (11) - s-a conchis că această distanță trebuie, de asemenea, evaluată de către histopatolog pe piesa formolizată şi nu intraoperator de către chirurg (12-14);

3. Tumorile sunt maligne (11). Doar în privinţa cancerelor se poate discuta despre secvenţele sincron-metacron, în ceea ce priveşte tumorile benigne, inclusiv cele cu potenţial de malignizare (adenoame, polipi), aceşti termeni sunt încă utilizaţi în mod eronat $(1,4,11,15)$.

Se speculează că cele mai multe dintre tumorile multiple cu localizare la nivelul colonului şi rectului se asociază cu bolile intestinale inflamatorii intestinale (16-18) sau se încadrează într-un sindrom de tumori maligne ereditare, fie polipozic, cum este polipoza adenomatoasă familială, fie nonpolipozic, cum este sindromul Lynch (18-22). De asemenea, se consideră că, în cazul cancerelor multiple sporadice, este foarte frecvent vorba, mai degrabă, despre o subdiagnosticare a sindroamelor de aglutinare familială sau a bolilor inflamatorii $(7,20,23-27)$.

\section{MATERIALE ŞI METODE}

Pentru aprofundarea cancerelor multiple, au fost evaluaţi 30 de pacienţi care au dezvoltat 3 sau mai multe tumori maligne multiple. Studiul are un caracter retrospectiv, informaţiile fiind obţinute din documentele medicale ale pacienţilor internaţi în secţia de Chirurgie Generală II a Spitalului de Urgenţă Bucureşti în perioada 2010-2019. Formaţiunile tumorale au întrunit criteriile detaliate mai sus, iar diagnosticul tumorilor a avut diferite secvenţe sincron-metacron. Doi pacienţi din lot au dezvoltat cea de-a patra patologie malignă şi doar unul pe cea de-a cincea.

Prima tumoră a seriei a fost numită tumoră index, după cum a fost stabilit încă din anul 1964 de către Moertel $(10,11)$. În cadrul acestui studiu, cea de-a doua tumoră malignă diferită poartă numele de tumoră secundam, în timp ce tumora a treia a fost numită tumoră terţă. În cazul existenţei unei serii de mai multe tumori maligne distincte, am decis numărătoarea acestora în continuare cu numere romane (IV, V, VI etc). Doar 2 pacienţi din lot au dezvoltat mai mult de 3 patologii maligne diferite. Trebuie menţionat faptul că niciunul dintre pacienţi nu a prezentat recidivă locală după tumora index sau secundam, recidiva fiind unul dintre criteriile de excludere în studiul expus.

\section{REZULTATE}

Dintre cei 30 de pacienţi evaluaţi în secţia de chirurgie II a Spitalului Universitar de Urgenţă Bucureşti, 27 au avut cel puţin una dintre localizările cancerelor, situată la nivelul colonului sau rectului, acest fapt datorându-se în parte preponderenţei acestei patologii în secţia noastră şi adresabilităţii crescute a pacienţilor cu cancer colo-rectal către secţiile de chirurgie generală, monitorizarea lor pe termen lung, decelând astfel apariţia cancerelor multiple.

Dintre cei 30 de pacienţi diagnosticaţi cu 3 cancere diferite, 19 au fost femei şi 11 bărbaţi.

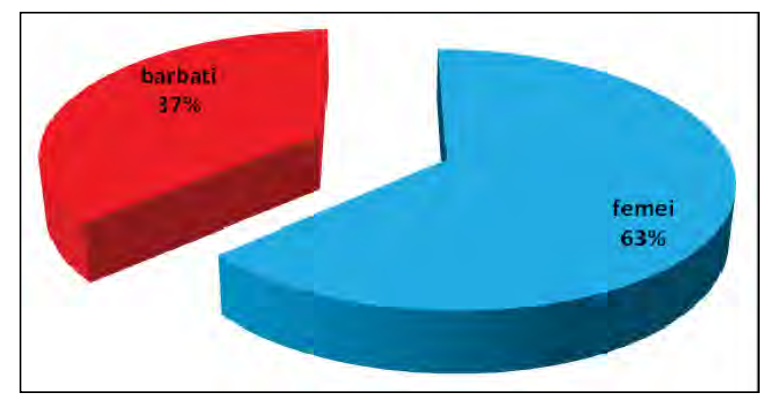

FIGURA 1. Distribuţia pacienţilor cu tumori multiple în funcţie de sex

În ceea ce priveşte istoricul familial, în cadrul studiului, am considerat că au antecedente heredocolaterale de cancer doar pacienţii care au avut o rudă de gradul I sau II diagnosticată cu patologie 
malignă, informaţie anamnestică şi nu neapărat susţinută de documente medicale ale rudelor. S-a constatat astfel că cea mai mare parte a pacienţilor lotului au avut antecedente heredocolaterale de cancer, după cum se evidenţiază în figura 2 .

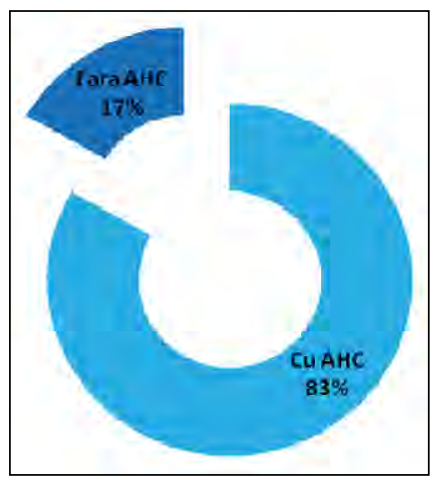

FIGURA 2. Distribuţia pacienţilor în funcţie de antecedentele heredocolaterale

Distribuţia în timp a tumorilor multiple a fost variată, astfel că unii pacienţi au prezentat tumora index şi tumora secundam în secvenţialitate sincronă, în timp ce tumora terţă a fost prezentată la mai mult de 6 luni de primele două; alţi pacienţi au prezentat tumorile secundam şi terţă la interval ce poate fi considerat succesiune sincronă, dar la mai mult de 6 luni de tumora index. Un singur pacient a prezentat toate cele trei tumori maligne în mod sincron, fiind diagnosticat simultan cu tumori maligne de cec, transvers şi rect dezvoltate pe fondul unei polipoze colonice. Cei mai mulţi dintre pacienţi au dezvoltat tumorile la mai mult de 6 luni distanţă în timp una de cealaltă.

TABELUL 1. Tipurile de succesiune a tumorilor maligne în lotul studiat

\begin{tabular}{|l|c|}
\hline \multicolumn{1}{|c|}{ Secvență de succesiune } & $\begin{array}{c}\text { Numărul de pacienți din } \\
\text { lotul de studiu }\end{array}$ \\
\hline Secvenţă $[\operatorname{Sincr}(1+2)+3]$ & $\mathbf{4}$ pacienţi \\
\hline Secvenţă $[1+\operatorname{Sincr}(2+3)]$ & $\mathbf{8}$ pacienţi \\
\hline Secvenţă $[\operatorname{Sincr}(1+2+3)]$ & $\mathbf{1}$ pacienţi \\
\hline Metacrone $(1)+(2)+(3)$ & $\mathbf{1 7}$ pacienţi \\
\hline Total & $\mathbf{3 0}$ pacienţi \\
\hline
\end{tabular}

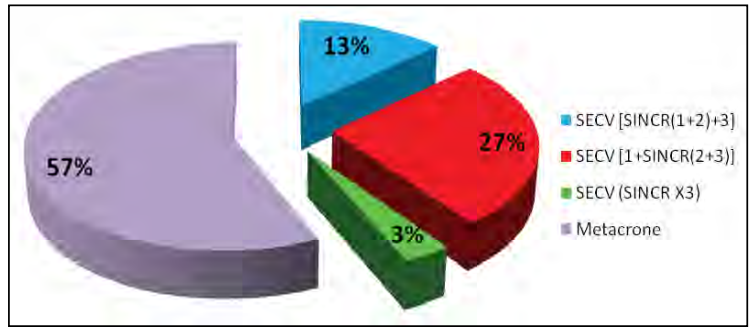

FIGURA 3. Distribuţia pacienţilor în funcţie de tipul de succesiune a tumorilor
Din punctul de vedere al perioadei de timp liber de boală, au fost evaluate perioadele parcurse între diagnosticul tumorii index şi al tumorii secundam şi, pe lângă secvenţele descrise mai sus, s-au evaluat perioadele de timp în care s-au diagnosticat cele mai multe dintre tumorile secundam şi terţe, după cum se evidenţiază în figura 4.

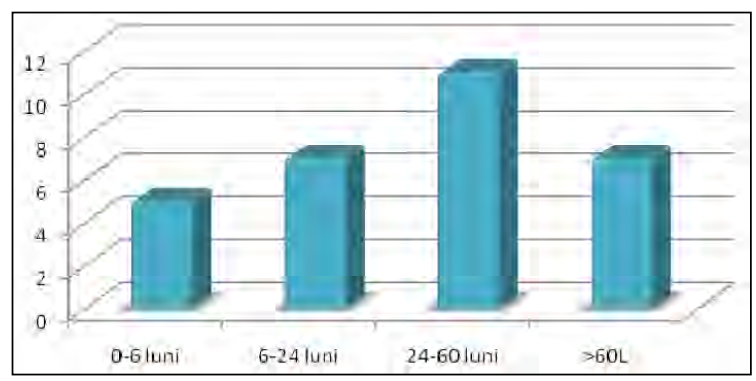

FIGURA 4. Durata de timp dintre tumora index şi tumora secundam

Se constată astfel că cele mai multe dintre tumorile secundam (37\%) au apărut între 2 ani şi 5 ani de la diagnosticul tumorii index. Tot în acest interval s-au înregistrat, după cum se vede în figura 5, şi cele mai multe diagnostice ale tumorilor terţe, $50 \%$ dintre pacienţii lotului fiind diagnosticaţi cu cel de-al treilea cancer în această perioadă şi numai $20 \%$ dezvoltând tumora terţă la mai mult de 5 ani.

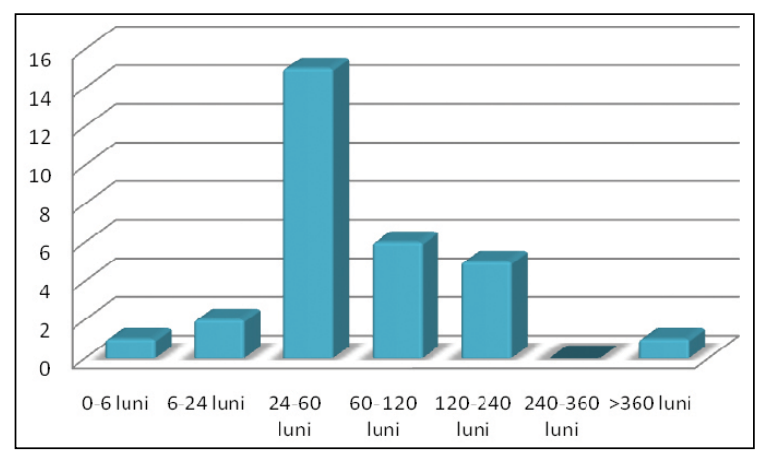

FIGURA 5. Durata de timp între tumora index şi tumora terţă

\section{CONCLUZII}

Formele multiple de manifestare ale cancerului reprezintă încă o patologie insuficient descrisă şi cercetată, necesitatea abordării tumorilor sincrone şi metacrone din perspectiva sindroamelor de aglutinare familială dovedindu-se importantă.

Nomenclatura tumorilor sincrone şi metacrone nu este încă suficient clarificată şi necesită completări atât în ceea ce priveşte secvenţierea în timp, cât şi în privinţa localizărilor. 
Cei mai mulţi dintre pacienţii care dezvoltă un al doilea sau al treilea cancer o fac în intervalul 2-5 ani, ceea ce impune un screening adecvat în această perioadă.

Deşi costurile sunt ridicate, testarea genetică a pacienţilor care dezvoltă tumora secundam ar pu- tea contribui la un diagnostic precoce sau chiar la evitarea dezvoltării tumorii terţe, dar, mai important decât atât, ar putea oferi un sfat genetic important familiei.
Conflict of interest: none declared
Financial support: none declared

\section{BIBLIOGRAFIE}

1. Allemani C, Matsuda T, Di Carlo V, Harewood R, Matz M, Nikšić M et al. Global surveillance of trends în cancer survival 2000-14 (CONCORD-3): Analysis of individual records for 37513025 patients diagnosed with one of 18 cancers from 322 population-based registries în 71 countries. Lancet. 2018;391(10125):1076-1084.

2. Masvidal Calpe R, Codina Cazador A, Farrés Coll R, Alcobilla Ferrara E, Gómez Castella F, Gironés Vila J. Synchronous colonic and rectal carcinomas. Rev Esp Enferm Dig. 1993;84(4):231-4.

3. Win AK, Parry S, Parry B, Kalady MF, Macrae FA, Ahnen DJ et al. Risk of metachronous colon cancer following surgery for rectal cancer în mismatch repair gene mutation carriers. Ann Surg Oncol. 2013; 20(6):1829-36.

4. Testori A, Cioffi U, De Simone M, Bini F, Vaghi A, Lemos AA et al. Multiple primary synchronous malignant tumors. BMC Res Notes. 2015; 15(04) 1724-5.

5. Ueno M, Muto T, Oya M, Ota H, Azekura K, Yamaguchi T. Multiple primary cancer: An experience at the Cancer Institute Hospital with special reference to colorectal cancer. Int J Clin Oncol. 2003; 8(3):162-167.

6. Ng AK, Travis LB. Subsequent malignant neoplasms în cancer survivors. Cancer $\mathrm{J}$. 2008; 14(6):429-34.

7. Syngal S. Sensitivity and specificity of clinical criteria for hereditary non-polyposis colorectal cancer associated mutations în MSH2 and MLH1. J Med Genet. 2000; 37(9):641-5.

8. Talley A. NCCN Clinical Practice Guidelines în Oncology (NCCN Guidelines $®$ ) Pancreatic Adenocarcinoma. Pancreas. 2013; 32(1):74-85.
9. Uk CR. Worldwide cancer statistics. Cancer research UK. 2014. 9:572-584.

10. Moertel CG. Adenocarcinoma of unknown origin. Annals of Internal Medicine. 1979; 91(4):646-647.

11. Moertel CG. Incidence and significance of multiple primary malignant neoplasms. Ann N Y Acad Sci. 1964;114(2):886-895.

12. Billroth $T$. Pathology and therapeutics, în fifty lectures. 1871. Clin Orthop Relat Res. 2003; 408(408):4-11.

13. Jagelman DG, DeCosse JJ, Bussey HJ. Upper gastrointestinal cancer în familial adenomatous polyposis. Lancet, 1988;331(8595):1149-1151.

14. Hu H, Chang DT, Nikiforova MN, Kuan SF, Pai RK. Clinicopathologic features of synchronous colorectal carcinoma: A distinct subset arising from multiple sessile serrated adenomas and associated with high levels of Microsatellite instability and favorable prognosis. Am J Surg Pathol. 2013; 37(11):1660-70.

15. Vogt A, Schmid S, Heinimann $K$, Frick $H$, Herrmann C, Cerny T et al. Multiple primary tumours: Challenges and approaches, a review. ESMO Open. 2017. 2(2):172-175.

16. Hemminki K, Li X, Sundquist J, Sundquist $\mathrm{K}$. Cancer risks în Crohn disease patients. Ann Oncol. 2009;20(3):574-580.

17. M'Koma AE. Inflammatory bowel disease: An expanding global health problem. Clinical Medicine Insights: Gastroenterology. 2013. 14(6):33-47.

18. Stidham RW, Higgins PDR. Colorectal cancer în inflammatory bowel disease. Clin Colon Rectal Surg. 2018; 31(03):168-178.

19. Amersi F, Agustin M, Ko CY. Colorectal cancer: Epidemiology, risk factors, and health services. Clinics în Colon and Rectal Surgery. 2005;18(3):133-40.
20. Wells K, Wise PE. Hereditary Colorectal Cancer Syndromes. Surgical Clinics of North America. 2017. 97(3):605-625.

21. Yurgelun MB, Kulke MH, Fuchs CS, Allen BA, Uno H, Hornick JL et al. Cancer susceptibility gene mutations în individuals with colorectal cancer. J Clin Oncol. 2017; 35(10):1086-1095.

22. Munck A, Gargouri L, Alberti C, Viala J, Peuchmaur M, Lenaerts $C$ et al. Evaluation of guidelines for management of familial adenomatous polyposis în a multicenter pediatric cohort. J Pediatr Gastroenterol Nutr. 2011; 53(3):296-302.

23. Beggs AD, Latchford AR, Vasen HFA, Moslein G, Alonso A, Aretz S et al. Peutz - Jeghers syndrome: A systematic review and recommendations for management. Gut. 2010 Jul;59(7):975-86.

24. Parry S, Win AK, Parry B, Macrae FA, Gurrin LC, Church JM et al. Metachronous colorectal cancer risk for mismatch repair gene mutation carriers: The advantage of more extensive colon surgery. Gut. 2011; 60 (7) 950-957.

25. Castillejo A, Vargas G, Castillejo MI, Navarro M, Barberá VM, González S et al. Prevalence of germline MUTYH mutations among Lynch-like syndrome patients. Eur J Cancer. 2014; 50(13):2241-50.

26. Fleming M, Ravula S, Tatishchev SF, Wang HL. Colorectal carcinoma: Pathologic aspects. J Gastrointest Oncol. 2012; 3(3):153-73.

27. Rex DK. Optimal withdrawal and examination în colonoscopy. Gastroenterology Clinics of North America. 2013. 42(3):429-42. 